szczędził wysiłków, aby wesprzeć pedagogów w ich działaniu edukacyjnym. Autorka wymienia i charakteryzuje szereg przedsięwzięć, które miały służyć rozpowszechnieniu idei spółdzielczości wśród nauczycieli: organizowanie specjalnych kursów dla opiekunów spółdzielni uczniowskich, sprawowanie nad spółdzielniami opieki gospodarczo-instruktażowej oraz propagowanie edukacji spółdzielczej na łamach prasy i w obrębie spółdzielczych księgarni nauczycielskich.

Rozprawę zamykają uwagi końcowe, które - przez umiejętne wyeksponowanie najważniejszych wniosków badawczych - stanowią doskonałe podsumowanie całej pracy.

Odbiorca recenzowanej książki pozostanie z pewnością pod wrażeniem nakładu pracy Autorki, która przekłada się nie tylko na liczbę stron (a tych jest - bez bibliografii 520), ale na zdolność przełożenia wielowątkowej problematyki na spójną i logiczną narrację. Pracowitość Autorki podkreślają dodatkowo podstawy źródłowe pracy. Dość wspomnieć, że sama bibliografia zajmuje w recenzowanej pracy aż 47 stron i obejmuje m.in. materiały źródłowe archiwalne, czasopisma, dzienniki urzędowe, księgi pamiątkowe, sprawozdania szkolne oraz pamiętniki.

Uwagę zwraca również strona edytorska książki. Staranność wydania, dbałość o przypisy, a także zamieszczone ilustracje z pewnością ułatwiają odbiór publikacji. Pewien niedosyt budzi natomiast brak indeksu osobowego, który pozwoliłby odbiorcy na szybkie odszukanie w treści książki interesujących go osób.

Praca E. Magiery przez wnikliwe zgłębienie problematyki nie tylko na trwałe wpisuje się w historiografię prac o edukacji spółdzielczej, ale i stanowić będzie punkt odniesienia dla wszystkich przyszłych rozpraw na ten temat.

Joanna Król

\title{
Philippe Ariès, Historia dzieciństwa. Dziecko i rodzina w czasach ancien régi- me'u, Wyd. Aletheia, Warszawa 2010, ss. 335
}

W subdyscyplinie, którą jest historia wychowania sięganie do francuskiej literatury przedmiotu ma długą tradycję. W należącym do klasyki podręczniku Stanisława Kota, Historia wychowania tych odniesień jest wiele, pojawiają się m.in. nazwiska historyków, takich jak np. G. Boissier, H.J. Leblanc, M. Fournier. Pamiętamy również oszałamiający erudycją cykl wykładów H.-I. Marrou w Historii wychowania w starożytności (1969), czy należące do klasyki opracowanie A. Joberta poświęcone KEN (1979), ze wskazaniem przedwojennego stanu źródeł historycznych, co było szczególnie cenne dla późniejszych badaczy, którzy mogli zebrać materiały rozproszone i przetrzebione w wojennej zawierusze.

W latach trzydziestych XX w. we Francji zespół francuskich historyków skupionych wokół czasopisma naukowego Annales d'histoire économique et sociale (Roczniki historii ekonomicznej $i$ społecznej) stworzył nowy styl uprawiania historiografii, w którym zerwano z dominacją historii politycznej, większy nacisk kładąc na konteksty społeczne, 
ekonomiczne, gospodarcze, antropologiczne i psychologiczne badanych zagadnień. W tym celu chętnie korzystano z dorobku innych nauk, przede wszystkim socjologii, geografii, ekonomii i historii sztuki. Z czasem uczonych, którzy przyjęli wypracowaną metodologię nazwano „Szkołą Annales”, a wśród jej założycieli wymieniano Luciena Febvre'a i Marca Blocha, znanego w Polsce z ponadczasowego dzieła Pochwała historii czyli o zawodzie historyka $(1962)^{1}$.

Do trzeciej generacji uczonych związanych ze „Szkołą Annales” należy Philippe Ariès, który w szeroko zakrojonych badaniach nad ludzką mentalnością łączy wiedzę z historii wychowania, psychologii dziecka, socjolologii rodziny, antropologii i nade wszystko z historii sztuki, do zasobów której nieustannie się odwołuje.

Pierwsze wydanie jego książki p.t. L'enfant et la vie familiale sous l'Ancien Régime pojawiło się we Francji w 1960 r. nakładem wydawnictwa Plon, kolejne w 1973 r. nakładem Edtions du Seuil. Oba te wydania zawierają bogatą ikonografię przedstawiającą artefakty (malarstwo, arrasy, ryciny, relief, rzeźby w tym stelle nagrobne) należące do europejskiego dziedzictwa kultury. Są reprezentowane przez artystów tej miary co P. de Champaigne, N. Arnoult, J.Callot, H. Holbein, J. Lagniet, S. Leclerc, Le Nain, Crispin de Pos, J. Nocret. Ukazują portrety dzieci, ich rodziców i opiekunów, ubiór i zabawki, gry i zabawy dziecięce, atrybuty szkolne, wnętrza pomieszczeń i plenery będące tłem scen z życia rodzinnego i codziennych obowiązków. Ich wieloaspektowa analiza stanowiła znaczący wkład do rozważań autora nad życiem i pozycją dziecka oraz kondycją rodziny w dawnych czasach. Wszak obraz jest także odzwierciedleniem emocjonalnego stanu utrwalonego w mimice twarzy, gestach rąk, mowie ciała przedstawianych osób. Kolejne wydania francuskie z Edtions du Seuil z lat 1975 i 1990 były wersjami skróconymi. Część I i III zostały zachowane w całości, z siedmiu rozdziałów części II wybrano tylko naistotniejsze fragmenty. Wydania te nie zawierały również warstwy ilustracyjnej, jedynie odwołanie do wydania oryginalnego. O skali tych zmian świadczy liczba ponad dwustu utraconych stron.

Niestety, to właśnie na skróconym wydaniu z 1975 r. oparła się tłumaczka Maryna Ochab, kiedy w 1995 r. po raz pierwszy przybliżyła dzieło Ph. Ariès polskim czytelnikom, nakładem gdańskiego wydawnictwa Marabut. Warto zauważyć, że chociaż stało się to nie tylko ponad pół wieku od premiery książki, ale także jedenaście lat po śmierci autora, to nadal pozostaje aktualne ${ }^{2}$. Tym bardziej, że w Polsce literatura przedmiotu poświęcona historii dzieciństwa w dawnych czasach była skromna ${ }^{3}$. W 2010 r. pojawiło

\footnotetext{
1 Nazwa pochodzi od francuskojęzycznego czasopisma naukowego wydawanego od 1929 r. (od roku 1946 nosi tytuł: Annales. Economies, sociétés, civilizations), które wraz z wieloma książkami i monografiami stanowi materiał źródłowy. Szkoła odegrała istotną rolę w określeniu kształtu historiografii na całym świecie.

2 Philippe Ariès urodził się w 1914 r. w Bordeaux, zmarł w 1984 r. w Paryżu. Historyk mediewista. Był profesorem w Ėcole des Hautes Etudes en Sciences Sociales (Wyższa Szkoła Nauk Socjalnych). Do najważniejszych publikacji należą: Czas historii (1954), Historia dzieciństwa. Dziecko i rodzina w czasach ancien régime'u (1960), Rozważania o historii śmierci (1975), Człowiek i śmierć (1977). W nawiasach podane są lata ich oryginalnych wydań. Polskie tłumaczenia pochodzą z lat dziewięćdziesiątych ubiegłego wieku.

${ }^{3}$ Z historyków oświaty zajmowała się tą problematyką tylko jedna badaczka, Dorota Żołądź-Strzelczyk (Dziecko w dawnej Polsce).
} 
się drugie wydanie Historii dzieciństwa. Dziecko i rodzina w czasach ancien régime'u autorstwa Philippe Ariès, tej samej tłumaczki, nakładem warszawskiego wydawnictwa Aletheia w serii z klepsydrą, również niezawierające ilustracji. W dobie cywilizacji obrazkowej jest to duży mankament, aczkolwiek można znaleźć ratunek w internecie w postaci skanów użytej w oryginale ikonografii. Polskie wydania różnią się szatą graficzną i niewielkimi, raczej kosmetycznymi zmianami w tekście. W obu wydaniach na okładce znalazły się krótkie noty o autorze i książce.

Pierwsze wydanie książki (1995) w opracowaniu graficznym Tomasza Bogusławskiego ma format A3 i twardą okładkę z niezbyt szczęśliwie dobraną fotografią pochodzącą z XIX w. z polskich zbiorów (na co wskazuje logo fotografa), ukazującą chłopca w marynarskim ubranku. Jest to w sprzeczności z oryginalnym tytułem książki, który odnosi się do ancien régime’u, czyli czasów od średniowiecza po wiek XVIII. Gwoli ścisłości, wydawać by się mogło, że ów tytuł jest lekkim nadużyciem autora, bo najwięcej jego analiz i opisów dotyczy wieku XVI i XVII. Czasy wcześniejsze są tylko nakreśleniem kontekstu. Zaś, zwłaszcza w przedmowie, odniesienia do XIX i XX w. są wskazaniem kontinuum bądź zasadniczej zmiany w postrzeganiu dziecka (młodzieńca) i jego sytuacji. Jednak Ariès stawia tezę, że odkrycie dzieciństwa nastąpiło dopiero u schyłku XIII w. wraz z odkryciem nieśmiertelności duszy dziecka. Pojęcie to rozwinęło się jeszcze w późniejszym okresie (wiek XV i XVI) i wiązało się także z rozwojem uczuć rodzicielskich, co miało zasadniczy wpływ na zmianę obrazu dziecka. Również w polskiej literaturze mamy tego wzruszający dowód w Trenach Kochanowskiego. W polskich wydaniach oryginalny tyłuł stał się podtytułem, poprzedzony został bardziej pojemnym treściowo tytułem: Historia dzieciństwa. Jednak przyjąwszy powyższą tezę autora można uznać go za uprawniony.

Drugie wydanie książki (2010) jest mniejszego formatu (A5) i w miękkiej oprawie. Projekt okładki Grzegorza Laszuka przedstawiający fragment obrazu Philippe'a de Champaigne, Les Enfants Habert de Montmort (1649) wyraźnie nawiązuje do treści i ikonografii książki Philippe'a Ariès. W drugim wydaniu zostały uporządkowane i uzupełnione przypisy, a tłumaczenia tekstów łacińskich powędrowały z przypisów do nawiasów w tekście, co jest korzystnym zabiegiem ułatwiającym czytanie. Przejrzystą strukturę książki tworzy 14 rozdziałów zawartych w III częściach zorientowanych wokół problematyki dotyczącej Dzieciństwa (cz. I, 5 rozdz.), Szkoły (cz. II, 7 rozdz.), Rodziny (cz. III, 2 rozdz.), zaopatrzonych w konkluzje będące odpowiedzią na postawione tezy. Zakończenie stanowi podsumowanie rozważań autora. Książka zawiera również przedruk przedmowy Philippe’a Ariès do francuskiego wydania z 1973 r. Literatura, do której odwołuje się autor, jak również niezbędne objaśnienia bogatej terminologii używanej $\mathrm{w}$ opisie np. periodyzacji dzieciństwa, pochodzenie omawianych w tekście artefaktów zostały zamieszczone w solidnie udokumentowanych przypisach. Być może w ten sposób został trochę złagodzony brak ilustracji.

Literackim walorem książki jest znakomite tłumaczenie dokonane przez Marynę Ochab. Zapewne nie było to zadanie łatwe, bo francuskich autorów o starannym klasycznym wykształceniu, wśród nich także Philippe’a Ariès, wyróżnia niesłychane bogactwo i zarazem elegancja warstwy językowej. Autor używa na przykład całego zakresu okre- 
śleń dotyczących dziecka w różnych okresach jego rozwoju, cech charakteru, pozycji społecznej itd., należących zarówno do terminologii naukowej, jak potocznego języka, a tłumaczka dzielnie i z dużym wyczuciem mu w tym sekunduje. Dzięki temu również czytelnik wzbogaca swój język o słowa, które już coraz rzadziej albo wcale goszczą we współczesnej polszczyźnie.

Jak wyżej powiedziano, Philippe Ariès rozpoczyna swoją książkę od rozważań o dzieciństwie, którego przez wiele stuleci nie dostrzegano jako odrębnej kategorii. W małym dziecku widziano miniaturę dorosłego człowieka. Często nawet ubiór i narzucony styl bycia był tego dowodem. Nieidentyfikowano jego potrzeb. Kiedy osiagało ono dojrzałość fizyczną natychmiast stawało się dorosłym osobnikiem. Dopiero wiek początek wieku XVII przynosi zasadniczą zmianę i według Ph. Ariés można uznać w nim umowną granicę $\mathrm{w}$ sposobie przedstawiania dzieci w sztuce i literaturze. Pojawiają się wówczas wdzięczne portrety dzieci i ich rodziców w sielskich scenach rodzinnych i wspólnych grach i zabawach, których autor przytacza całą gamę. Wiele z nich jest nadal dzisiaj znanych i praktykowanych. Z tą różnica, że właśnie w XVII w. zaczęto rozróżniać gry i zabawy dla dorosłych i dzieci, bo wcześniej wszyscy bawili się jak... dzieci. Zaś dzieciom do XIX w. nikt nie bronił gier hazardowych, zarezerwowanych później tylko dla dorosłych. Część I kończy rozdział o znamiennym tytule Od bezwstydu do niewinności, który współcześnie, ze względu na debatę o wychowaniu seksualnym jest szczególnie interesujący i pouczający. Aczkolwiek w dobie poprawności politycznej i terroru złego dotyku może być bulwersujący. Jak pisze Ariés chociaż ,zdumiewa nas ten brak zahamowań wobec dzieci, ta swoboda języka i śmiałość gestów” [s. 151], to wiedzieć należy, że „postawa człowieka wobec seksu, tak samo jak i sam seks, zmieniają się w zależności od środowiska, a zatem także od epoki i mentalności." [151]. Jeszcze w XVI i XVII w. uważano, że sprawy płci są dla małego dziecka obce i obojętne, to też dotykanie narządów płciowych i żartobliwe aluzje traktowano najzupełniej naturalnie, bo nie dopatrywano się w tym seksualności. Ariés na podstawie dziennika królewskiego lekarza J. Héroarda przytacza liczne przykłady z życia kilkuletniego delfina Ludwika XIII, który w bardzo swobodny sposób traktował siebie i swoje otoczenie w poznawaniu ciała i jego tajników. Kiedy delfin ukończył siedem lat skończyły się tego rodzaju zabawy, bowiem od małego mężczyzny wymagano powściągliwości w zachowaniu. Stopniowo zmieniał się również pogląd na seksualność dzieci, zamiast niewinności dostrzeżono bezwstyd, nad którym trzeba zapanować, stosując różne praktyki wychowawcze i restrykcje, by przywrócić niewinność. Przedstawicielem tego nurtu był J. Gerson, doskonały obserwator dzieci i ich praktyk seksualnych. W wieku XVII obok traktatów adresowanych do dzieci pojawia się również literatura pedagogiczna na użytek rodziców i wychowawców. W nowej moralnej koncepcji dzieciństwa nacisk kładzie się na jego bezbronność, którą łączy się z niewinnością będącą odbiciem boskiej czystości. Pojawia się krytyka zarówno postawy obojętności wobec dziecka, jak nadmiernej czułostkowości i pobłażliwości oraz egoistycznego czynienia zeń zabawki. Nacisk kładzie się na świadome wychowanie i opiekę nad dzieckiem.

Współcześnie w edukacji małych Szwajcarów na etapie wychowania przedszkolnego pojawiają się tzw. sex boxy zawierające pomoce dydaktyczne w rodzaju drewnianych 
penisów i gąbczastych wagin, które zaleca się do zabawy dzieciom, aby nauczyły się rozróżniać męskie i żeńskie organy płciowe i wiedziały do czego służą, zaś małym Szwedom i Norwegom w nauczaniu początkowym zaleca się, by dotykały miejsc intymnych, wzajemnie uczyły się swej nagości, a nawet masturbowały się, by poznać związane z tym emocje. Owa edukacja seksualna przebiega z śmiertelną powaga pod kontrolą specjalistów: pedagogów, psychologów i seksuologów. Jej skutki nie są jeszcze w pełni rozpoznane.

Kolejne części książki poświęcone są rodzinie i różnym aspektom historii edukacji będących dowodem ewolucji postawy wobec dzieciństwa w ludzkiej mentalności. W średniowieczu kształcenie odnosiło się do garstki dzieci i młodzieży, nie rzadko także dorosłych mężczyzn, gdyż wiek ucznia nie stanowił kryterium dla odbywających wspólnie naukę. Zresztą, jak pisze Ariès, ,wymieszanie wieku tak naturalne, że nawet nie dostrzegane, to jedna $\mathrm{z}$ najbardziej charakterystycznych, a zarazem najtrwalszych, bo głęboko zakorzenionych w życiu cech dawnego społeczeństwa" [s. 200]. U schyłku średniowiecza kiedy owo wymieszanie wieku zaczyna budzić niechęć, narastają dążenia do oddzielenia najmłodszych, ale jest to proces długi i niełatwy, który nie powiódł się w pełni, bo liczył się przedmiot nauczania a nie wiek audytorium. Dopiero w XIX w. z jednej strony odseparowano dzieci najmłodsze od starszych, z drugiej - bogatych od biednych, dla których edukacja a wraz z nią dzieciństwo kończyło się znacznie wcześniej. Skutkiem troski o wykształcenie dzieci jest w XVII wieku nadzwyczajny rozwój szkół. Warto zwrócić uwagę na rozważania Ariès na temat rozwoju i znaczenia dyscypliny w szkołach, zwłaszcza w kolegiach, przy których lokowane były internaty. Autor przytacza przykłady licznych kar fizycznych i upokorzeń, którym podlegali uczniowie, W większym stopniu dotyczyło to dzieci o niższej pozycji społecznej [s. 215-216].

Ariès przypomina również, że regularne kształcenie odnosiło się głównie do płci męskiej, dziewczynki przygotowywane do roli gospodyń i matek pobierały naukę w niewielkim zakresie. Nawet klasztory, do których oddawano zwyczajowo dziewczęta nie wywiązywały się właściwie z tej roli, edukację zastępując praktykami religijnymi.

W ostatniej części - poświęconej rodzinie, Ariès w oparciu o ogromny materiał ilustracyjny pokazuje powolny proces zmian w niej zachodzących w zależności od jej pozycji społecznej i miejsca pochodzenia. Rodzina przestaje być instytucją prawa spadkowego w celu przekazywania gromadzonego przez pokolenia rodowego majątku, a staje się prywatną wspólnotą dzieci i rodziców, opartą na fundamencie miłości ,zacznie pełnić funkcje moralne i duchowe, kształtować dusze i ciała” [s. 331]. Skutkiem emocjonalnego zbliżenia członków rodziny jest zanik obyczaju oddawania dzieci na wychowanie innym rodzinom. Przegrywa nawet szkoła na rzecz edukacji domowej. Rośnie rola piastunek, niań i guwernerów sprowadzanych do prywatnej przestrzeni domów rodzinnych, ale Ariès nie dostrzega tych relacji. A przecież literatura dostarcza przykładów silnych związków emocjonalnych między nianią a jej wychowankiem. Ten problem nie jest również obcy zapracowanym rodzicom w XXI w. W czasach nowożytnych rodzina i szkoła definitywnie wydzielą dziecko ze społeczeństwa dorosłych.

Historię dzieciństwa Philippe Ariès czyta się wspaniale. A co najważniejsze lektura skłania do refleksji nad kondycją człowieka, także tego małego człowieka, którego świat 
i relacje w nim zachodzące na przestrzeni wieków autor odkrywa przed czytelnikiem. Zaś historykom oświaty dostarcza wiele przykładów świetnie ilustrujących zajęcia dydaktyczne oraz, co najważniejsze, wskazuje niezbadane jeszcze obszary wiedzy.

Jolanta Szablicka

\section{Czesław Kupisiewcz, $Z$ dziejów teorii $i$ praktyki wychowania, Oficyna Wydawnicza „Impuls”, Warszawa 2012, ss. 322}

Nakładem Oficyny Wydawniczej „Impuls”, specjalizującej się w literaturze naukowej, ukazał się niedawno podręcznik akademicki $Z$ dziejów teorii i praktyki wychowania. Autorem książki jest nestor polskiej pedagogiki, zwany „Nauczycielem nauczycieli”, profesor Czesław Kupisiewicz. Ten uczony z wieloletnim dorobkiem podjął się napisania pozycji, która w efekcie finalnym ma przystępny charakter wprowadzający nie tylko dla studentów pedagogiki i nauczycieli, ale także wszystkich osób mających coś wspólnego z oświatą i edukacją, a nawet jest atrakcyjna dla czytelników zainteresowanych poszerzeniem horyzontów umysłowych i wiedzy o kulturze humanistycznej Zachodu.

Problem wychowania nie jest bowiem zagadnieniem błahym ani abstrakcyjnym. Wychowanie, jak definiuje autor, to ogót czynności zwiqzanych z oddziaływaniem środowiska przyrodniczego i społecznego na człowieka, ksztattujacych jego osobowość i trwajacych przez cate życie. Wychowanie nie ogranicza się zatem do okresu dzieciństwa i młodości, jest procesem trwającym permanentnie. Prawidłowe wychowanie może wzmacniać i stymulować podstawy funkcjonowania jednostek oraz społeczeństwa, a nawet powodować, że dana cywilizacja (jak na przykład antyczna cywilizacja grecka z jej ideałem kalokagatii), wznosi się na wyżyny ducha i twórczej ekspresji kulturowej. Nieprawidłowe zaś wychowanie, wynikające ze złych wpływów środowiska, może doprowadzić na przykład do przestępczości. Jak pisze Locke, jeden z wielu autorów omawianych przez Kupisiewcza: „Z dziesięciu ludzi, których spotykamy, dziewięciu jest tym, czym jest: złymi lub dobrymi, pożytecznymi lub szkodliwymi dla społeczeństwa - dzięki wychowaniu".

Pierwsze wrażenie z obcowania czytelniczego z książką Kupisiewcza jest niezwykle przyjemne. Podręcznik jest atrakcyjny w lekturze, zawierający w sobie bardzo uporządkowany i oszczędny materiał. Każdy rozdział posiada swoje wyszczególnienia, streszczające tezy omawianych koncepcji i myślicieli (z których prawie każdy posiada swoją małą ilustrację w książce), zawsze odnajdziemy również w danej partii tekstu zgrabne podsumowanie oraz słownik najważniejszych przywoływanych teminów. Zarazem książka posiada bardzo skondensowaną dawkę syntezy z dziejów całej zachodniej myśli pedagogicznej, dotyczącej teorii i praktyki wychowania.

Wrażenia po dłuższej lekturze książki Kupisiewcza także są pozytywne. Autor przeprowadza czytelnika, niczym Charon przez Styks, przez złożone i wielowątkowe dzieje myśli pedagogicznej oraz instytucji, zajmujących się wychowywaniem. Na kartach pod- 